\title{
AN ASSESSMENT AND MODELING OF CRITICAL SUCCESS FACTORS OF INDIAN AGRICULTURE USING INTERPRETIVE STRUCTURAL MODELLING AND MICMAC ANALYSIS
}

\author{
Bhavesh Dave \\ Research Scholar \\ Department of Mechanical Engineering \\ Ujjain Engineering College, Ujjain, M.P., India
}

\begin{abstract}
The aim of this paper is to analyse the most practiced Critical Success Factors (CSFs) for Indian agriculture. India is an agricultural country. Approximately three-fourth population of India is primarily dependent on agriculture for their livelihood. Therefore, any improvement in agriculture can provide impetus to Indian economy. The success of this approach is rooted on the understanding of different enablers of Indian agriculture. The most commonly accepted CSFs for Indian agriculture were indentified from the literature. Then by agricultural expert's opinion, interactions among those CSFs have been studied using Interpretive Structural Modeling (ISM). The findings through MICMAC analysis implied that most of the CSFs are classified as linkage variables and remaining are classified as Independent variables. The developed model provides a road map that assists practitioners to understand the process through which CSFs are practiced in a certain enterprise.
\end{abstract}

Keywords- Indian agriculture, Critical Success Factors, MICMAC Analysis, Interpretive Structural Modeling

\section{INDRODUCTION}

Agriculture in India is livelihood for a long majority of population and can never be underestimated. Contribution of agriculture in the gross domestic product (GDP) of India has increased to $19.9 \%$ in 2020-21 from $17.8 \%$ in $2019-20$. This has made us self sufficient and taken us from being a begging bowl for food after independence to a net exporter of

\author{
Dr. Vijay Kumar Sukhwani \\ Professor \\ Department of Mechanical Engineering \\ Ujjain Engineering College, Ujjain, M.P., India
}

agriculture and allied products [1]. In this paper, we emphasis on Indian agricultural sector, where Indian government has built symbolic policies for viable growth [2] but still not much advancement has been done yet. In the beginning phase of independence, the Indian economy was majorly agrarian with more than $70 \%$ of people dependent on agriculture [3]. Thus agriculture contributed most of the India's GDP. However, many challenges have been emerged for Indian farmers which include unemployment, limited land resources, unavailability of water and electricity, climate changes, debasement of natural resources, enhancing population pressure, and variation in demand and consumption patterns [4]. Farmers also do not have enough access to resources like sufficient farming skills, agricultural technology inputs, marketing channels and funding sources. Consequently, the preferred quality and productivity have not been achieved in this sector [5].

The main objective of this research study is to analyse the CSFs of Indian agriculture and modeling the interaction among them. Structural modeling of selected CSFs is crucial to enhance the effectiveness of Indian agricultural practices because it provides the inter-relation among different CSFs at different levels which is a challenging task. So it is necessary to estimate optimal solution in terms of modeling the interactions among CSFs of Indian agriculture using a vigorous technique. In this context, ISM has been used for analysis and modeling CSFs of Indian agriculture that results in productive approach of agricultural practices.

In this paper, author has also focused on grouping of these CSFs into different clusters like Independent, dependent, linkage and autonomous variables using MICMAC approach. The present work has been 


\section{International Journal of Engineering Applied Sciences and Technology, 2021 Vol. 6, Issue 3, ISSN No. 2455-2143, Pages 161-166 \\ Published Online July 2021 in IJEAST (http://www.ijeast.com)}

organized into six sections including introduction as $1^{\text {st }}$ section. $2^{\text {nd }}$ Section represents literature review pertaining to Indian agriculture, critical success factors, ISM and MICMAC analysis. Furthermore, $3^{\text {rd }}$ section represents methodology followed in this research; ISM. The discussion of this research work has been represented in the $4^{\text {th }}$ section of the manuscript. The $5^{\text {th }}$ section of the article represents conclusions, limitations and future scope of the present research study.

\section{LITERATURE REVIEW}

This section consists of literature search methodology, a summary of literature available on Interpretive Structural Modeling (ISM), MICMAC analysis, Critical Success Factors, Indian agriculture. The end of section consists of research gap in this field.

ISM is an approach that converts indefinite and deficiently expressed intellectual models into detailed useful model for many purposes [6], ISM assists individual and group of experts in identifying the relationship among different factors, barriers, elements or any set of entities [7], Overview of Interpretive Structural Modeling has been briefly explained with significance of self interaction matrix, reachability matrix, transitivity check [8], method has also been used to identify and solve the problems of supplier selection [9]. It has also been used to prioritizing critical success factors [10] and set of enablers, ranking set of barriers [11]. Recent research on ISM includes broad area of engineering and management such as Supply Chain Management (SCM) [12], entrepreneurship, green SCM, Human Resource Management (HRM), evaluation of performance and energy management [13].

An analysis of critical success factor for six sigma implementation based on Automotive Service Industry case study and literature review by ISM model has been done and all the factors were found to be linkage factors [14]. The research work on the implementation of Toyota production system (TPS) in Indian MSMEs in terms of motive, barriers, challenges, success factor and applications has been done which is among very limited number of studies. Its findings were based on company's believe in benefits of TPS practices and willing to change for sustainability of business [15]. The Research work on Green lean six sigma enabler identification and its modeling using ISM to meticulously adjudicate interactions among the enablers has been done. Result of this study by MICMAC analysis showed that all enablers except one were found to be linkage variables [16].

MICMAC (Matrice d'Impacts croisesmultiplication application) analysis consists of a system having multiplication of matrices developed by (Duperrin and Godet, 1973). In this method, Indirect relationships is majorly used to justify importance of a variable rather than using direct relationship [17]. Previous studies [8] also shows MICMAC analysis based on conical matrix and a graph showing driving and dependence power. MICMAC analysis has been used in various real life applications like driving and dependence power analysis of knowledge management variables [18], analysis of drivers affecting green supply chain management [19]. For clarification and management of a variable behavior in the system has been classified by MICMAC analysis [20].

The CRFs indicate those factors which are considered "critical" to the success of any organization or firm and, consequently, failing in achieving the relative goals of these factors shows disastrous failure of the entire firm [21]. There is a very thin line between the general term success factors and specific term enablers, but both these terms are different in definition and application [14].

Identification of drivers for implementation of lean and green manufacturing from literature review and expert's opinion, consequently ranking of drivers by TOPSIS method \& (SAW) in Fuzzy environment for Indian manufacturing SMEs have been done. [22]. An assessment of critical success factor for empirical investigation of six sigma status in Indian industry has been performed by survey questionnaire method. Result of this empirical study reflect the impact of different CSFs in Indian SMEs [23].

In this research study, for the selection of critical success factors of Indian agriculture, author systematic reviewed various literature like predictive factors affecting Indian Rural Farm Youth's Decisions to Stay in or Leave Agriculture Sector [24], Socio-economic factors affecting adoption of modern information and communication technology by farmers in India by Multivariate Probit Model [25], Factors affecting the use of ICT's on agricultural input information by farmers in developing countries [26], Indian agriculture and farmer's problems and reforms and some others. Then by combining all these CSFs, removing common factors and merging some of the factors author prepared list of $15 \mathrm{CSFs}$ (Table 2.1) for further analysis. 


\section{International Journal of Engineering Applied Sciences and Technology, 2021 Vol. 6, Issue 3, ISSN No. 2455-2143, Pages 161-166 \\ Published Online July 2021 in IJEAST (http://www.ijeast.com)}

Table 2.1 List of Critical Success Factors of Indian agriculture

\begin{tabular}{|c|c|}
\hline Acronym & Critical Success Factors \\
\hline CSF1 & Limited subsistence in agriculture \\
\hline CSF2 & Limited dominance of food grains \\
\hline CSF3 & Mixed cropping \\
\hline CSF4 & $\begin{array}{c}\text { Rimited intensive agriculture } \\
\text { technology }\end{array}$ \\
\hline CSF5 & $\begin{array}{c}\text { Availability of water for effective } \\
\text { irrigation }\end{array}$ \\
\hline CSF6 & $\begin{array}{c}\text { Good area under leguminous and } \\
\text { fodder crops }\end{array}$ \\
\hline CSF7 & $\begin{array}{c}\text { Effective government policies } \\
\text { indebtness of farmers }\end{array}$ \\
\hline CSF8 & $\begin{array}{c}\text { providing research and } \\
\text { educational training }\end{array}$ \\
\hline CSF9 & $\begin{array}{c}\text { Effective Warehouse and Storage } \\
\text { facility }\end{array}$ \\
\hline CSF10 & Green purchasing \\
\hline CSF11 & Globalisation of agriculture \\
\hline CSF12 & $\begin{array}{c}\text { Effect of good fertilizers and } \\
\text { pesticides }\end{array}$ \\
\hline CSF13 & Availability of transport facility \\
\hline CSF14
\end{tabular}

The research in field of Indian agriculture has been done to identify the problems of farmers and some ideas have been given to reform that [27]. Research on Indian agriculture GDP and non performing assets has been done by performing feature engineering on the factors affecting the agricultural GDP using the data from 1961 to 2019 by Regression model [28]. A detailed and broad theoretical study on Organic Farming problems for Sustainable agriculture and reform to it has been given by expert's opinion [29]. Development of agricultural entrepreneur inclination model for sustainable agriculture by integrating expert mining and ISM-MICMAC has been done and findings show that agripreneur courses, agricultural policies, training and development modules, government cooperation and the involvement of institutional heads play an essential role towards agripreneurship [30].

Thus research has been done in Indian agricultural sector and in other sectors or SMEs by ISM methodology or MICMAC analysis. But by the best of our knowledge there is a research gap of structural inter-relation of critical success factors of Indian agriculture. There is a huge scope of research in this field. In this paper, Author has worked on assessment and modeling of various CSFs of Indian agriculture by Interpretive Structural Modeling and MICMAC analysis.

\section{RESEARCH METHODOLOGY}

Interpretive Structural Modeling introduced by Warfield (1974) and Sage (1977) is an alternation of paired-comparison approach. It is generally a computer-aided and has the ability to regulate group input. It assists in identification of the interrelationships among enablers under study. ISM is an interactive learning process, in which a set of differently and directly related enablers are framed into a comprehensive systematic model. Thus generated model depicts the structure of a complex issue or problem, a field or a system of study, in a precisely framed pattern including words as well as graphics [31]. The ISM methodology is interpretive such that judgments of the groups decide whether the enablers are interrelated or not. It is structural as well because combined structure is taken out from the complex set of variables on the basis of interactions among them.

3.1. Development of structural self-interaction matrix:

ISM methodology relies on the opinion of the experts for developing structural self-interaction matrix (SSIM). In this study, an offline questionnaire survey was conducted. Because of more number of critical success factors involved under study and inability of most of the target experts to feed online data, total 15 experts from the Indian agriculture and farmers from different villages were consulted for identifying the contextual relationship among the CSFs of agricultural practices. Then final interaction matrix is prepared by entering data having highest repeatability of $\mathrm{V}, \mathrm{A}, \mathrm{O}$ and $\mathrm{X}$ in each cell. Thus contextual relationship between variables is developed and is presented in Table 3.1. The notations used for representing the type of relation between a pair of CSFs are:

- $\mathrm{V}$ for the relation from $\mathrm{i}$ to $\mathrm{j}$ but not in both directions;

- A for the relation from $\mathrm{j}$ to $\mathrm{i}$ but not in both directions;

- $\mathrm{X}$ for both direction relations from $\mathrm{i}$ to $\mathrm{j}$ and $\mathrm{j}$ to $\mathrm{i}$;

- $\mathrm{O}$ for both direction relations do not exist from $i$ to $j$ and $j$ to $i$; 
Table 3.1 Structural self interaction matrix

\begin{tabular}{|c|c|c|c|c|c|c|c|c|c|c|c|c|c|c|}
\hline CSFs & $\mathbf{1 5}$ & $\mathbf{1 4}$ & $\mathbf{1 3}$ & $\mathbf{1 2}$ & $\mathbf{1 1}$ & $\mathbf{1 0}$ & $\mathbf{9}$ & $\mathbf{8}$ & $\mathbf{7}$ & $\mathbf{6}$ & $\mathbf{5}$ & $\mathbf{4}$ & $\mathbf{3}$ & $\mathbf{2}$ \\
\hline $\mathbf{1}$ & $\mathrm{O}$ & $\mathrm{A}$ & $\mathrm{O}$ & $\mathrm{X}$ & $\mathrm{O}$ & $\mathrm{A}$ & $\mathrm{V}$ & $\mathrm{O}$ & $\mathrm{A}$ & $\mathrm{A}$ & $\mathrm{V}$ & $\mathrm{V}$ & $\mathrm{X}$ & $\mathrm{O}$ \\
\hline $\mathbf{2}$ & $\mathrm{V}$ & $\mathrm{V}$ & $\mathrm{X}$ & $\mathrm{X}$ & $\mathrm{X}$ & $\mathrm{A}$ & $\mathrm{X}$ & $\mathrm{X}$ & $\mathrm{A}$ & $\mathrm{A}$ & $\mathrm{X}$ & $\mathrm{A}$ & $\mathrm{X}$ & \\
\hline $\mathbf{3}$ & $\mathrm{O}$ & $\mathrm{V}$ & $\mathrm{X}$ & $\mathrm{X}$ & $\mathrm{X}$ & $\mathrm{A}$ & $\mathrm{X}$ & $\mathrm{A}$ & $\mathrm{A}$ & $\mathrm{A}$ & $\mathrm{X}$ & $\mathrm{A}$ & & \\
\hline $\mathbf{4}$ & $\mathrm{O}$ & $\mathrm{V}$ & $\mathrm{V}$ & $\mathrm{V}$ & $\mathrm{O}$ & $\mathrm{A}$ & $\mathrm{V}$ & $\mathrm{O}$ & $\mathrm{O}$ & $\mathrm{X}$ & $\mathrm{X}$ & & & \\
\hline $\mathbf{5}$ & $\mathrm{O}$ & $\mathrm{X}$ & $\mathrm{V}$ & $\mathrm{V}$ & $\mathrm{O}$ & $\mathrm{A}$ & $\mathrm{O}$ & $\mathrm{O}$ & $\mathrm{O}$ & $\mathrm{X}$ & & & & \\
\hline $\mathbf{6}$ & $\mathrm{A}$ & $\mathrm{V}$ & $\mathrm{V}$ & $\mathrm{O}$ & $\mathrm{A}$ & $\mathrm{O}$ & $\mathrm{V}$ & $\mathrm{X}$ & $\mathrm{V}$ & & & & & \\
\hline $\mathbf{7}$ & $\mathrm{O}$ & $\mathrm{V}$ & $\mathrm{V}$ & $\mathrm{V}$ & $\mathrm{V}$ & $\mathrm{O}$ & $\mathrm{V}$ & $\mathrm{O}$ & & & & & & \\
\hline $\mathbf{8}$ & $\mathrm{A}$ & $\mathrm{V}$ & $\mathrm{X}$ & $\mathrm{V}$ & $\mathrm{O}$ & $\mathrm{A}$ & $\mathrm{V}$ & & & & & & & \\
\hline $\mathbf{9}$ & $\mathrm{A}$ & $\mathrm{V}$ & $\mathrm{V}$ & $\mathrm{X}$ & $\mathrm{X}$ & $\mathrm{A}$ & & & & & & & & \\
\hline $\mathbf{1 0}$ & $\mathrm{V}$ & $\mathrm{V}$ & $\mathrm{V}$ & $\mathrm{V}$ & $\mathrm{V}$ & & & & & & & & & \\
\hline $\mathbf{1 1}$ & $\mathrm{V}$ & $\mathrm{O}$ & $\mathrm{X}$ & $\mathrm{O}$ & & & & & & & & & & \\
\hline $\mathbf{1 2}$ & $\mathrm{O}$ & $\mathrm{A}$ & $\mathrm{A}$ & & & & & & & & & & & \\
\hline $\mathbf{1 3}$ & $\mathrm{X}$ & $\mathrm{V}$ & & & & & & & & & & & & \\
\hline $\mathbf{1 4}$ & $\mathrm{O}$ & & & & & & & & & & & & & \\
\hline $\mathbf{1 5}$ & & & & & & & & & & & & & & \\
\hline
\end{tabular}

\subsection{Development of Initial reachability matrix}

SSIM is then converted into a binary matrix, known as the initial reachability matrix as shown in Table 3.2. The initial reachability matrix is developed according to following substitution rules:

- If the $(i, j)$ cell value in the SSIM is $V$, the $(i, j)$ input in the reachability matrix becomes 1 and the $(\mathrm{j}$, i) input becomes 0 .
- If the $(i, j)$ cell value in the SSIM is A, the $(i, j)$ input in the reachability matrix becomes 0 and the $(\mathrm{j}$, i) input becomes 1 .

- If the $(i, j)$ cell value in the SSIM is $X$, the $(i, j)$ input in the reachability matrix becomes 1 and the $(\mathrm{j}$, i) input also becomes 1 .

- If the $(i, j)$ cell value in the SSIM is $O$, the $(i, j)$ input in the reachability matrix becomes 0 and the $(j$, i) input also becomes 0 .

Table 3.2 Initial reachability matrix

\begin{tabular}{|c|c|c|c|c|c|c|c|c|c|c|c|c|c|c|c|}
\hline CSFs & $\mathbf{1}$ & $\mathbf{2}$ & $\mathbf{3}$ & $\mathbf{4}$ & $\mathbf{5}$ & $\mathbf{6}$ & $\mathbf{7}$ & $\mathbf{8}$ & $\mathbf{9}$ & $\mathbf{1 0}$ & $\mathbf{1 1}$ & $\mathbf{1 2}$ & $\mathbf{1 3}$ & $\mathbf{1 4}$ & $\mathbf{1 5}$ \\
\hline $\mathbf{1}$ & 1 & 0 & 1 & 1 & 1 & 0 & 0 & 0 & 1 & 0 & 0 & 1 & 0 & 0 & 0 \\
\hline $\mathbf{2}$ & 0 & 1 & 1 & 0 & 1 & 0 & 0 & 1 & 1 & 0 & 1 & 1 & 1 & 1 & 1 \\
\hline $\mathbf{3}$ & 1 & 1 & 1 & 0 & 1 & 0 & 0 & 0 & 1 & 0 & 1 & 1 & 1 & 1 & 0 \\
\hline $\mathbf{4}$ & 0 & 1 & 1 & 1 & 1 & 1 & 0 & 0 & 1 & 0 & 0 & 1 & 1 & 1 & 0 \\
\hline $\mathbf{5}$ & 0 & 1 & 1 & 1 & 1 & 1 & 0 & 0 & 0 & 0 & 0 & 1 & 1 & 1 & 0 \\
\hline $\mathbf{6}$ & 1 & 1 & 1 & 1 & 1 & 1 & 1 & 1 & 1 & 0 & 0 & 0 & 1 & 1 & 0 \\
\hline $\mathbf{7}$ & 1 & 1 & 1 & 0 & 0 & 0 & 1 & 0 & 1 & 0 & 1 & 1 & 1 & 1 & 0 \\
\hline $\mathbf{8}$ & 0 & 1 & 1 & 0 & 0 & 1 & 0 & 1 & 1 & 0 & 0 & 1 & 1 & 1 & 0 \\
\hline $\mathbf{9}$ & 0 & 1 & 1 & 0 & 0 & 0 & 0 & 0 & 1 & 0 & 1 & 1 & 1 & 1 & 0 \\
\hline $\mathbf{1 0}$ & 1 & 1 & 1 & 1 & 1 & 0 & 0 & 1 & 1 & 1 & 1 & 1 & 1 & 1 & 1 \\
\hline $\mathbf{1 1}$ & 0 & 1 & 1 & 0 & 0 & 1 & 0 & 0 & 1 & 0 & 1 & 0 & 1 & 0 & 1 \\
\hline $\mathbf{1 2}$ & 1 & 1 & 1 & 0 & 0 & 0 & 0 & 0 & 1 & 0 & 0 & 1 & 0 & 0 & 0 \\
\hline $\mathbf{1 3}$ & 0 & 1 & 1 & 0 & 0 & 0 & 0 & 1 & 0 & 0 & 1 & 1 & 1 & 1 & 1 \\
\hline
\end{tabular}




\begin{tabular}{|l|l|l|l|l|l|l|l|l|l|l|l|l|l|l|l|}
\hline $\mathbf{1 4}$ & 1 & 0 & 0 & 0 & 1 & 0 & 0 & 0 & 0 & 0 & 0 & 1 & 0 & 1 & 0 \\
\hline $\mathbf{1 5}$ & 0 & 0 & 0 & 0 & 0 & 1 & 0 & 1 & 1 & 0 & 0 & 0 & 1 & 0 & 1 \\
\hline
\end{tabular}

3.3 Development of final reachability matrix

Then, transitivity check of individual factor is executed, considering the assumption that if CSF1 leads to successful implementation of CSF2, and CSF2 leads to successful implementation of CSF3, then CSF1 leads to successful implementation of CSF3. Consequently, some inputs in the initial reachability matrix are converted from 0 to 1 . The converted inputs are labeled by “*” as shown in final reachability matrix (Table3.3).

Table 3.3. Final reachability matrix

\begin{tabular}{|c|c|c|c|c|c|c|c|c|c|c|c|c|c|c|c|c|}
\hline CSFs & $\mathbf{1}$ & $\mathbf{2}$ & $\mathbf{3}$ & $\mathbf{4}$ & $\mathbf{5}$ & $\mathbf{6}$ & $\mathbf{7}$ & $\mathbf{8}$ & $\mathbf{9}$ & $\mathbf{1 0}$ & $\mathbf{1 1}$ & $\mathbf{1 2}$ & $\mathbf{1 3}$ & $\mathbf{1 4}$ & $\mathbf{1 5}$ & $\begin{array}{c}\text { Driving } \\
\text { power }\end{array}$ \\
\hline $\mathbf{1}$ & 1 & $1^{*}$ & 1 & 1 & 1 & 0 & 0 & 0 & 1 & 0 & $1^{*}$ & 1 & $1^{*}$ & $1^{*}$ & 0 & $\mathbf{1 0}$ \\
\hline $\mathbf{2}$ & $1^{*}$ & 1 & 1 & $1^{*}$ & 1 & 0 & 0 & 1 & 1 & 0 & 1 & 1 & 1 & 1 & 1 & $\mathbf{1 2}$ \\
\hline $\mathbf{3}$ & 1 & 1 & 1 & $1^{*}$ & 1 & 0 & 0 & $1^{*}$ & 1 & 0 & 1 & 1 & 1 & 1 & $1^{*}$ & $\mathbf{1 2}$ \\
\hline $\mathbf{4}$ & $1^{*}$ & 1 & 1 & 1 & 1 & 1 & 0 & $1^{*}$ & 1 & 0 & $1^{*}$ & 1 & 1 & 1 & $1^{*}$ & $\mathbf{1 3}$ \\
\hline $\mathbf{5}$ & $1^{*}$ & 1 & 1 & 1 & 1 & 1 & 0 & $1^{*}$ & $1^{*}$ & 0 & $1^{*}$ & 1 & 1 & 1 & $1^{*}$ & $\mathbf{1 3}$ \\
\hline $\mathbf{6}$ & 1 & 1 & 1 & 1 & 1 & 1 & 1 & 1 & 1 & 0 & $1^{*}$ & $1^{*}$ & 1 & 1 & $1^{*}$ & $\mathbf{1 4}$ \\
\hline $\mathbf{7}$ & 1 & 1 & 1 & $1^{*}$ & $1^{*}$ & 0 & 1 & $1^{*}$ & 1 & 0 & 1 & 1 & 1 & 1 & $1^{*}$ & $\mathbf{1 3}$ \\
\hline $\mathbf{8}$ & $1^{*}$ & 1 & 1 & 0 & $1^{*}$ & 1 & 0 & 1 & 1 & 0 & $1^{*}$ & 1 & 1 & 1 & $1^{*}$ & $\mathbf{1 2}$ \\
\hline $\mathbf{9}$ & $1^{*}$ & 1 & 1 & 0 & $1^{*}$ & 0 & 0 & $1^{*}$ & 1 & 0 & 1 & 1 & 1 & 1 & $1^{*}$ & $\mathbf{1 1}$ \\
\hline $\mathbf{1 0}$ & 1 & 1 & 1 & 1 & 1 & 0 & 0 & 1 & 1 & 1 & 1 & 1 & 1 & 1 & 1 & $\mathbf{1 3}$ \\
\hline $\mathbf{1 1}$ & $1^{*}$ & 1 & 1 & 0 & $1^{*}$ & 1 & 0 & $1^{*}$ & 1 & 0 & 1 & $1^{*}$ & 1 & $1^{*}$ & 1 & $\mathbf{1 2}$ \\
\hline $\mathbf{1 2}$ & 1 & 1 & 1 & $1^{*}$ & $1^{*}$ & 0 & 0 & $1^{*}$ & 1 & 0 & $1^{*}$ & 1 & $1^{*}$ & $1^{*}$ & $1^{*}$ & $\mathbf{1 2}$ \\
\hline $\mathbf{1 3}$ & $1^{*}$ & 1 & 1 & 0 & $1^{*}$ & 0 & 0 & 1 & $1^{*}$ & 0 & 1 & 1 & 1 & 1 & 1 & $\mathbf{1 1}$ \\
\hline $\mathbf{1 4}$ & 1 & $1^{*}$ & $1^{*}$ & $1^{*}$ & 1 & 0 & 0 & 0 & $1^{*}$ & 0 & 0 & 1 & $1^{*}$ & 1 & 0 & $\mathbf{9}$ \\
\hline $\mathbf{1 5}$ & 0 & $1^{*}$ & $1^{*}$ & 0 & 0 & 1 & 0 & 1 & 1 & 0 & $1^{*}$ & $1^{*}$ & 1 & $1^{*}$ & 1 & $\mathbf{1 0}$ \\
\hline $\begin{array}{c}\text { Dependence } \\
\text { power }\end{array}$ & $\mathbf{1 4}$ & $\mathbf{1 5}$ & $\mathbf{1 5}$ & $\mathbf{1 0}$ & $\mathbf{1 4}$ & $\mathbf{6}$ & $\mathbf{2}$ & $\mathbf{1 3}$ & $\mathbf{1 5}$ & $\mathbf{1}$ & $\mathbf{1 4}$ & $\mathbf{1 5}$ & $\mathbf{1 5}$ & $\mathbf{1 5}$ & $\mathbf{1 3}$ & \\
\hline
\end{tabular}

\subsection{Level Partitioning}

The final reachability matrix obtained was partitioned into different levels. The reachability set and antecedent set for each CSF [32] were obtained from final reachability matrix (Table 3.3). The reachability set for a CSF consists of itself and the other CSFs. The antecedent set consists of the CSF itself and the other CSFs which may help in achieving it. The intersections of both these sets were obtained for all CSFs. If the reachability set and the intersection set for a CSF is the same, then that CSF is considered to be in level 1 and is given the top position in the ISM hierarchy [33]. Thus iteration 1 of level partitioning gets completed (Table 3.4). Similarly, next level iterations are performed by eliminating the CSFs of previous level from previous level iteration tables (Tables 3.5, 3.6, 3.7, 3.8). Final list of all the CSFs and consequently their level occupied in iterations are shown in Table 3.9.

\subsection{Formation of Interpretive Structural Model}

Final Interpretive model is formed by placing level 1 CSFs at the top of the hierarchy diagram, level 5 CSFs at last and remaining level of CSFs in between top and last place of hierarchy diagram (Figure 3.1). This hierarchy diagram shows inter-relation between all the CSFs of Indian agriculture under study. 
Table 3.4 Level 1 iteration

\begin{tabular}{|c|c|c|c|c|}
\hline CSFS & REACHABILITY SET & ANTECEDENT SET & INTERSECTION & LEVEL \\
\hline 1 & $1,2,3,4,5,9,11,12,13,14$ & $1,2,3,4,5,6,7,8,9,10,11,12,13,14$ & $1,2,3,4,5,9,11,12,13,14$ & I \\
\hline 2 & $1,2,3,4,5,8,9,11,12,13,14,15$ & $1,2,3,4,5,6,7,8,9,10,11,12,13,14,15$ & $1,2,3,4,5,8,9,11,12,13,14,15$ & I \\
\hline 3 & $1,2,3,4,5,8,9,11,12,13,14,15$ & $1,2,3,4,5,6,7,8,9,10,11,12,13,14,15$ & $1,2,3,4,5,8,9,11,12,13,14,15$ & I \\
\hline 4 & $1,2,3,4,5,6,8,9,11,12,13,14,15$ & $1,2,3,4,5,6,7,10,12,14$ & $1,2,3,4,5,6,12,14$ \\
\hline 5 & $1,2,3,4,5,6,8,9,11,12,13,14,15$ & $1,2,3,4,5,6,7,8,9,10,11,12,13,14$ & $1,2,3,4,5,6,8,9,11,12,13,14$ \\
\hline 6 & $1,2,3,4,5,6,7,8,9,11,12,13,14,15$ & $4,5,6,8,11,15$ & $4,5,6,8,11,15$ \\
\hline 7 & $1,2,3,4,5,7,8,9,11,12,13,14,15$ & 6,7 & 7 \\
\hline 8 & $1,2,3,5,6,8,9,11,12,13,14,15$ & $2,3,4,5,6,7,8,9,10,11,12,13,15$ & $2,3,5,6,8,9,11,12,13,15$ \\
\hline 9 & $1,2,3,5,8,9,11,12,13,14,15$ & $1,2,3,4,5,6,7,8,9,10,11,12,13,14,15$ & $1,2,3,5,8,9,11,12,13,14,15$ \\
\hline 10 & $1,2,3,4,5,8,9,10,11,12,13,14,15$ & 1 & 1 \\
\hline 11 & $1,2,3,5,6,8,9,11,12,13,14,15$ & $1,2,3,4,5,6,7,8,9,10,11,12,13,15$ & $1,2,3,5,6,8,9,11,12,13,15$ \\
\hline 12 & $1,2,3,4,5,8,9,11,12,13,14,15$ & $1,2,3,4,5,8,9,11,12,13,14,15$ & $1,2,3,4,5,8,9,11,12,13,14,15$ \\
\hline 13 & $1,2,3,5,8,9,11,12,13,14,15$ & $1,2,3,4,5,6,7,8,9,10,11,12,13,14,15$ & $1,2,3,5,8,9,11,12,13,14,15$ \\
\hline 14 & $1,2,3,4,5,9,12,13,14$ & $1,2,3,4,5,6,7,8,9,10,11,12,13,14,15$ & $1,2,3,4,5,9,12,13,14$ \\
\hline 15 & $2,3,6,8,9,11,12,13,14,15$ & $2,3,4,5,6,7,8,9,10,11,12,13,15$ & $2,3,6,8,9,11,12,13,15$ \\
\hline
\end{tabular}

Table 3.5 Level 2 iteration

\begin{tabular}{|c|c|c|c|c|}
\hline CSFS & REACHABILITY SET & ANTECEDENT SET & INTERSECTION & LEVEL \\
\hline 4 & $4,5,6,8,11,15$ & $4,5,6,7,10$ & $4,5,6$ \\
\hline 5 & $4,5,6,8,11,15$ & $4,5,6,7,8,10,11$ & $4,5,6,8,11$ \\
\hline 6 & $4,5,6,7,8,11,15$ & $4,5,6,8,11,15$ & $4,5,6,8,11,15$ \\
\hline 7 & $4,5,7,8,11,15$ & 6,7 & 7 & II \\
\hline 8 & $5,6,8,11,15$ & $4,5,6,7,8,10,11,15$ & $5,6,8,11,15$ \\
\hline 10 & $4,5,8,10,11,15$ & 10 & 10 & II \\
\hline 11 & $5,6,8,11,15$ & $4,5,6,7,8,10,11,15$ & $5,6,8,11,15$ & II \\
\hline 15 & $6,8,11,15$ & $4,5,6,7,8,10,11,15$ & $6,8,11,15$ & \\
\hline
\end{tabular}

Table 3.6 Level 3 iteration

\begin{tabular}{|c|c|c|c|c|}
\hline CSFS & REACHABILITY SET & ANTECEDENT SET & INTERSECTION & LEVEL \\
\hline 4 & $4,5,6$ & $4,5,6,7,10$ & $4,5,6$ & III \\
\hline 5 & $4,5,6$ & $4,5,6,7,10$ & $4,5,6$ & III \\
\hline 6 & $4,5,6,7$ & $4,5,6$ & $4,5,6$ & \\
\hline 8 & $5,6,8,11,15$ & $4,5,6,7,8,10,11,15$ & $5,6,8,11,15$ & III \\
\hline 10 & $4,5,10$ & 10 & 10 & \\
\hline
\end{tabular}

Table 3.7 Level 4 iteration 
International Journal of Engineering Applied Sciences and Technology, 2021

Vol. 6, Issue 3, ISSN No. 2455-2143, Pages 161-166

Published Online July 2021 in IJEAST (http://www.ijeast.com)

\begin{tabular}{|c|c|c|c|c|}
\hline CSFS & REACHABILITY SET & ANTECEDENT SET & INTERSECTION & LEVEL \\
\hline 6 & 6,7 & 6 & 6 & \\
\hline 7 & 7 & 6,7 & 7 & IV \\
\hline 10 & 10 & 10 & 10 & IV \\
\hline
\end{tabular}

Table 3.8 Level 5 iteration

\begin{tabular}{|c|c|c|c|c|}
\hline CSFS & REACHABILITY SET & ANTECEDENT SET & INTERSECTION & LEVEL \\
\hline 6 & 6 & 6 & 6 & $\mathrm{~V}$ \\
\hline
\end{tabular}

Table 3.9 Final list of CSFs and their occupied levels

\begin{tabular}{|c|c|c|c|c|}
\hline CSFs & REACHABILITY SET & ANTECEDENT SET & INTERSECTION & LEVEL \\
\hline 1 & $1,2,3,4,5,9,11,12,13,14$ & $1,2,3,4,5,6,7,8,9,10,11,12,13,14$ & $1,2,3,4,5,9,11,12,13,14$ & I \\
\hline 2 & $1,2,3,4,5,8,9,11,12,13,14,15$ & $1,2,3,4,5,6,7,8,9,10,11,12,13,14,15$ & $1,2,3,4,5,8,9,11,12,13,14,15$ & 1 \\
\hline 3 & $1,2,3,4,5,8,9,11,12,13,14,15$ & $1,2,3,4,5,6,7,8,9,10,11,12,13,14,15$ & $1,2,3,4,5,8,9,11,12,13,14,15$ & 1 \\
\hline 4 & $4,5,6$ & $4,5,6,7,10$ & $4,5,6$ & III \\
\hline 5 & $4,5,6$ & $4,5,6,7,10$ & $4,5,6$ & III \\
\hline 6 & 6 & 6 & 6 & $\mathrm{~V}$ \\
\hline 7 & 7 & 6,7 & 7 & IV \\
\hline 8 & $5,6,8,11,15$ & $4,5,6,7,8,10,11,15$ & $5,6,8,11,15$ & 11 \\
\hline 9 & $1,2,3,5,8,9,11,12,13,14,15$ & $1,2,3,4,5,6,7,8,9,10,11,12,13,14,15$ & $1,2,3,5,8,9,11,12,13,14,15$ & 1 \\
\hline 10 & 10 & 10 & 10 & IV \\
\hline 11 & $5,6,8,11,15$ & $4,5,6,7,8,10,11,15$ & $5,6,8,11,15$ & II \\
\hline 12 & $1,2,3,4,5,8,9,11,12,13,14,15$ & $1,2,3,4,5,8,9,11,12,13,14,15$ & $1,2,3,4,5,8,9,11,12,13,14,15$ & 1 \\
\hline 13 & $1,2,3,5,8,9,11,12,13,14,15$ & $1,2,3,4,5,6,7,8,9,10,11,12,13,14,15$ & $1,2,3,5,8,9,11,12,13,14,15$ & 1 \\
\hline 14 & $1,2,3,4,5,9,12,13,14$ & $1,2,3,4,5,6,7,8,9,10,11,12,13,14,15$ & $1,2,3,4,5,9,12,13,14$ & 1 \\
\hline 15 & $6,8,11,15$ & $4,5,6,7,8,10,11,15$ & $6,8,11,15$ & 11 \\
\hline
\end{tabular}




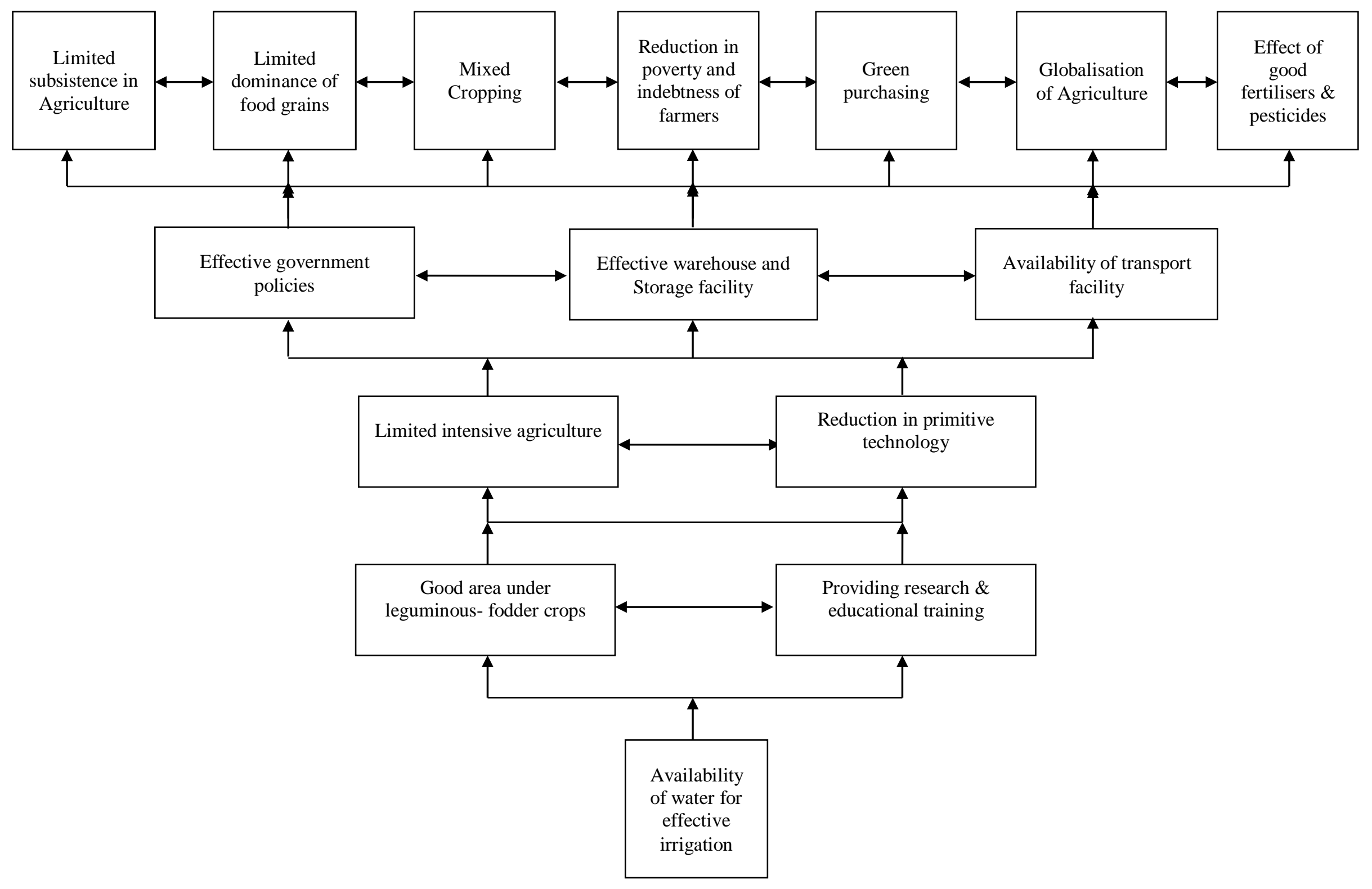

Figure 3.1 Developed Interpretive Structural Model 


\section{RESULTS AND DISCUSSION}

ISM is primarily used to classify the invested critical success factors or enablers on basis of driving power and dependence power into four clusters of Independent variables, dependent variables, linkage variable and autonomous variable. Zone of Independent variables contains those CSFs having strong driving power associated with weak dependence power. While in contrast, zone of dependent variables consists of strong dependence power associated with weak driving power. Zone of linkage variables contains strong dependence as well as driving power. While in contrast, zone of autonomous variables contains weak dependence and driving power.

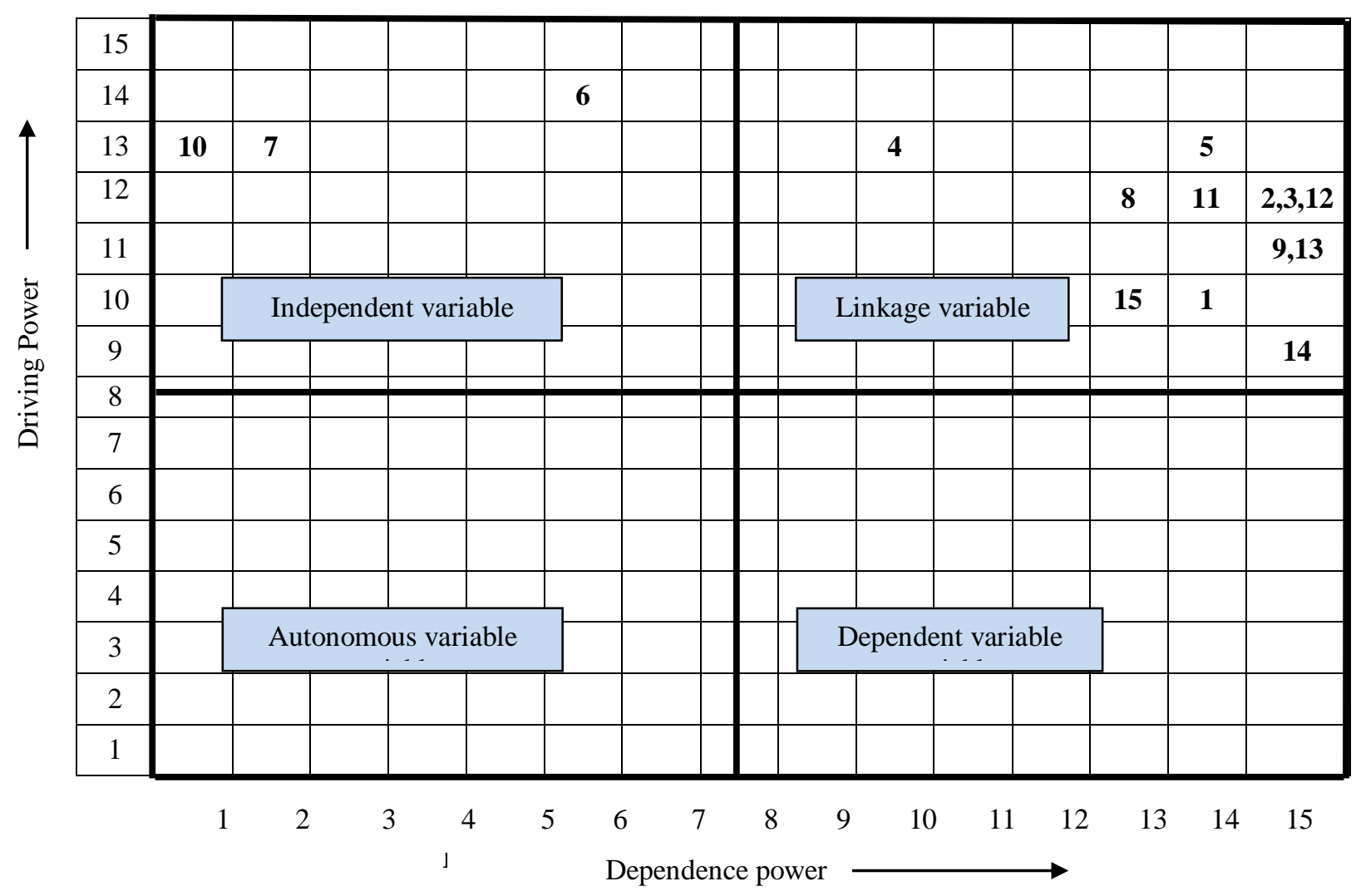

Figure 4.1 MICMAC Analysis of CSFs

Figure 4.1 indicates that there is no CSF in autonomous category which implies that, generally all CSFs are depending on each other. This output confirms the results of the previous literature studies, that is, all these 15 factors are critical for Indian Agriculture. More specifically, Figure 4.1 indicates that CSFs Limited subsistence in agriculture, limited dominance of food grains, mixed cropping, limited intensive agriculture, reduction in primitive technology, effective government policies, reduction in poverty \& indebtness of farmers, effective warehouse and storage facility, green purchasing, globalization of agriculture, effect of good fertilisers $\&$ pesticides and availability of transport facility are classified as linkage variables, which implies that the interaction among these factors plays a significant role in Indian Agriculture. If these variables are implemented in a systematic way they can create productive environment for Indian agriculture but adoption of these variables are majorly dependent on other CSF like availability of water for effective irrigation, good area under leguminous and fodder crops and providing research and educational training. Figure 4.1 also shows that none of the CSFs fall under cluster of dependent variables, which indicates there is no any CSF involved in study that has weak driving power and strong dependence power. Figure 4.1 further shows that good area under leguminous and fodder crops, providing research and educational training and availability of water for effective irrigation fall in cluster of Independent variables which indicate these CSF are having strong driving power and weak dependence power. These 


\section{International Journal of Engineering Applied Sciences and Technology, 2021 Vol. 6, Issue 3, ISSN No. 2455-2143, Pages 161-166 \\ Published Online July 2021 in IJEAST (http://www.ijeast.com)}

factors may be considered as 'key enablers' of Indian agriculture.

The levels of different CSFs are crucial for better understanding their implications in Indian agriculture. Figure 3.1 shows that limited subsistence in agriculture, limited dominance of food grains, mixed cropping, reduction in poverty and indebtness of farmers, green purchasing, globalisation of agriculture, effect of good fertilisers and pesticides are the top level CSFs. These all factors are impacted by lower level CSFs. The second level CSFs (effective government policies, effective storage and warehouse facility and availability of transport facility) and third level CSFs (limited intensive agriculture, reduction in primitive technology) are operational level CSFs that are crucial for effective Indian agricultural practices. Availability of water for effective irrigation occupy bottom level of hierarchy since it has highest driving power and lowest dependence which also indicates that this CSF play significant role and work as main CSF of Indian agricultural practices.

\section{CONCLUSION}

Agriculture is called as backbone of India's economic system because two third of Indian population is associated in cultivation of land. But the emerging problems that cause suffering to Indian agriculture at present are the knowledge deficit and infrastructure deficit, especially in the rural areas. Loopholes associated with Irrigation infrastructure, market infrastructure and transport infrastructure add compelling cost to farmer's operations. This research study can be concluded as-

1. Author has tried to assess factors that are critical for Indian agriculture and model them by ISM method and analyse them by MICMAC analysis. Fifteen CSFs pertain to Indian agriculture were found suitable for being modeled and analyzed.

2. The ISM decision making technique has been used for establishing the relationship or interaction among these CSFs of Indian agriculture. Seven CSFs forms the top most level of ISM model, three CSFs form second level of model, two CSFs form third level of model, again two CSFs form fourth level of model and "Availability of water for effective irrigation" forms the last level of model as shown in Figure 3.1.

3. Modeling of these CSFs facilitates the research practitioners to understand the inter-relationship and linkage of various CSFs. MICMAC analysis has been used to classify these CSFs into
Independent, dependent, linkage and autonomous variables that will facilitate the research practitioners and agricultural decision maker to fulfill effective development goals.

4. Twelve CSFs are found as linkage variables whereas three as driver or independent variables. None of the CSFs are found as dependent and autonomous variables.

5. The major intimation of the present research lies in suggesting further scope to research practitioners through investigation of relationship among different CSFs that gives a systematic way to initiate interpretive structural model. In general, researchers by adopting present approach can reproduce the similar results for the variables and CSFs related to their problems.

6. The main limitation of present research study is that the application of the proposed interpretive structural model is based on opinion of agricultural experts and farmers of different villages. This limitation provides the scope for future research work, as the biasness in expert's opinion and farmer's opinion can be reduced by different statistical tools. Moreover, the present model can also be validated by other modeling methodologies.

\section{REFERENCE}

1. Madhu Sharma, 2021 "The future of Indian agriculture,"

https://www.google.com/amp/s/www.downtoeart h.org.in/blog/agriculture/amp/the-future-ofindian-agriculture-75384.

2. Bell, C., \& Rich, R., 1994 "Rural poverty and aggregate agricultural performance in postindependent India," Oxford Bulletin of Economics and Statistics, 56(2), 111-133.

3. Geeta, P., 2013 "Agripreneurship education and development: Need of the day," Asian Resonance, 2(4), 155-157.

4. Jha, P., Makkad, M., \& Mittal, S., 2018 "Performance-oriented factors for women entrepreneurs-A scale development perspective," Journal of Entrepreneurship in Emerging Economies, 10(2), 329-360.

5. Acharya, S., 2007 "Agribusiness in India: Some facts and emerging issues," Agricultural Economics Research Review, 20(Conference Issue), 409-424.

6. Venkatesh, V.G., Rathi, S., Patwa, S., 2015 "Analysis on supply chain risks in Indian apparel retail chains and proposal of risk prioritization 


\section{International Journal of Engineering Applied Sciences and Technology, 2021 Vol. 6, Issue 3, ISSN No. 2455-2143, Pages 161-166 \\ Published Online July 2021 in IJEAST (http://www.ijeast.com)}

model using Interpretive structural modeling," J. Retail. Consum. Serv. 26, 153-167.

7. Kanungo, S. and Bhatnagar, V.V., 2002 "Beyond Generic Models for Information System Quality: The Use of Interpretive Structural Modeling (ISM)," Systems Research and Behavioral Science, 19, 531-549.

8. Ashok kumar, Dr. Vikram Singh, 2019 "Overview of interpretive structural modeling," International Journal of Engineering Applied Sciences and Technology, vol.4, Pages 536-540.

9. Kannan, G., Haq, A.N., Sasikumar, P., Arunachalam, S., 2008 "Analysis and selection of green suppliers using interpretative structural modeling and analytic hierarchy process," Int. J. Manag. Decis. Mak. 9 (2), 163-182.

10. Tripathy, S., Sahu, S. and Ray, P.K., 2013 "Interpretive Structural Modeling for Critical Success Factors of R\&D Performance in Indian Manufacturing Firms, Journal of Modeling in Management," 8, 212-240.

11. Raeesi, R., Dastrang, M., Mohammadi, S. and Rasouli, E., 2013 "Understanding the Interactions among the Barriers to Entrepreneurship Using Interpretive Structural Modeling," International Journal of Business and Management, 8, 56174.

12. SJ Gorane, Ravi Kant, 2013 "Modeling the SCM enablers: an integrated Ism-fuzzy MICMAC approach," Asia Pacific Journal of Marketing and Logistics, IISM: 1355-5855

13. Ansari, M.F., Kharb, R.K., Luthra, S., Shimmi, S.L. and Chatterji, S., 2013 "Analysis of Barriers to Implement Solar Power Installations in India Using Interpretive Structural Modeling Technique," Renewable and Sustainable Energy Reviews, 27, 163.

14. Hisham Alidrisi, 2014 "Prioritising critical success factors for six sigma implementation using interpretive structural modeling," Americal Jouranl of Industrial and Business Management 4 (12), 697.

15. Waseem Akhtar, Afsar Ansari, 2020 "The implementation of Toyota production system (TPS) in Indian MSMEs: a study on the motive barriers, challenges, success factor and applications," International Journal of Engineering Applied Sciences and Technology, vol. 4, pages 102-111.

16. Mahender singh Kaswan, Rajeev Rathi, 2019 "Analysis and modeling the enablers of Green Lean Six Sigma implementation using Interpretive Structural Modeling," Journal of Cleaner Production 231 (2019) 1182-1191.
17. 17 Saxena, J.P., Vrat, P., 1990 "Impact of indirect relationships in classification of variables micmac analysis for energy conservation," Syst. Res. 7 (4), 245-253.

18. Singh, M.D., Shankar, R., Narain, R., Agarwal, A., 2003 "An interpretive structural modeling of knowledge management in engineering industries," J. Adv. Manag. Res. 1 (1), 28-40.

19. Diabat, A., Govindan, K., 2011 "An analysis of the drivers affecting the implementation of green supply chain management," Resour. Conserv. Recycl. 55 (6), 659-667.

20. Chandramowli, S., Transue, M., Felder, F.A., 2011 "Analysis of barriers to development in landfill communities using interpretive structural modeling," Habitat Int. 35 (2), 246-253.

21. Rockart, J.F., 1979 "Chief executives define their own data needs, Harv. Bus," Rev. 57(2), 81-93.

22. Nevil S. Gandhi, Shashank J. Thanki, Jitesh J. Thakkar, 2018 "Ranking of drivers for integrated lean-green manufacturing for Indian manufacturing SMEs," Journal of Cleaner Production 171, 675-689.

23. Darshak A. Desai, Jiju Antony, MB Patel, 2012 "An assessment of the critical success factors for Six Sigma implementation in Indian industries," International Journal of productivity and performance management, ISSN: 1741-0401.

24. A Nag, S Kumar Jha, A Mohammad, S Maiti, J Gupta, DK Gosain, KK Datta, TK Mohanty, 2018 "Predictive factors affecting Indian rural farm youth's decisions to stay in or leave agriculture sector," Journal of Agricultural Science and technology 20 (2), 221-234.

25. Surabhi Mittal, Mamta Mehar, 2016 "Socioeconomic factors affecting adoption of modern information and communication technology by farmers in India: Analysis using multivariate probit model," The Journal of Agricultural Education and Extension 22 (2), 199-212.

26. Macire Kante, Robert Oboko, Christopher Chepken, 2016 "Factors affecting the use of ICTs on agricultural input information by farmers in developing countries," AIMS Agriculture and Food 1 (3), 315-329.

27. S.K. Goyal, Dr. jai P. Rai, Shree Ram Singh, 2016 "Indian Agriculture and Farmers-Problems and reforms," The Journal of Agricultural Education 79-87.

28. Bhoomika Jethwani, Devasya Dave, Tamanna Ali, Shraddha Phansalkar, Swati Ahhirao, 2021 "Indian agriculture GDP and non performing assets: A regression model," IOP Conference 
Series: Materials Science and Engineering 1042 (1), 012007.

29. M. Singh., 2021 "Organic farming and sustainable agriculture," Indian Journal of Organic Farming, vol. 1.

30. Kuldeep Singh, Madhvendra Misra, 2020 "How to bring positive societal change through Corporate Social Responsibility (CSR)? Modeling the social responsible enablers using ISM-MICMAC," IEEE Technology \& Engineering Management Conference (TEMSCON), 1-6.

31. Abid Haleem, Sushil, Mohammad Asim Qadri, Sanja Kumar, 2012 "Analysis of critical success factors of world class manufacturing practices: an application of Interpretative structural modeling and interpretative ranking process," production, planning \& control, 722-734.

32. Warfield, J.N., 1974 "Developing interconnection matrices in structural modeling," IEEE Transactions on Systems Man and Cybernetics, 4 (1), 81-87.

33. Kannan, G., Haq, A.N., Sasikumar, P., Arunachalam, S., 2008 "Analysis and selection Manag. Decis. Mak,” 9 (2), 163-182. 